\title{
Changes in DNA methylation during development in the B chromosome NOR of the grasshopper Eyprepocnemis plorans
}

\author{
M. D. LÓPEZ-LEÓN, J. CABRERO \& J. P. M. CAMACHO* \\ Departamento de Genética, Facultad de Ciencias, Universidad de Granada, E-18071 Granada, Spain
}

\begin{abstract}
Chromosomal patterns of DNA methylation were analysed by in situ digestion with restriction endonucleases in different stages of the life cycle in the grasshopper Eyprepocnemis plorans: 10-dayold embryos, last instar male nymphs and adults of both sexes. The results show that the nucleolus organizing region (NOR) located distally on the B chromosome is not methylated in embryos or in gastric caeca of adult males and females, but it is methylated in ovariole cells and spermatocytes in both last instar nymphs and adults. Demethylation of the B-NOR during early embryogenesis is proposed for the observed methylation pattern in embryos. Despite variation in methylation status through the life cycle, rRNA genes contained in the B-NOR were never observed to be active, which indicates that DNA methylation is not the direct cause of their inactivity. Other causes such as chromatin structure or repression by genes on A chromosomes are suggested.
\end{abstract}

Keywords: B chromosome, chromosome methylation pattern, Eyprepocnemis plorans, in situ digestion, in situ hybridization, rDNA.

\section{Introduction}

Increasing evidence has been accumulated in recent years for a role of methylation of cytosines within $\mathrm{CpG}$ dinucleotides in the regulation of gene expression in eukaryotes (Razin \& Riggs, 1980; Bird, 1986; Cedar, 1988; Razin \& Cedar, 1991; Yeivin \& Razin, 1993). This has become apparent, for instance, from the usual correlation between expression and under-methylation (Chapman et al., 1984; Ariel et al., 1991) and from changes in methylation patterns during development (Frank et al., 1991; Shemer et al., 1991; Fronk et al., 1992).

The differential sensitivity to methylation shown by certain restriction endonuclease isoschizomeres (e.g. MspI and HpaII) has become a powerful tool for analysing methylation patterns not only at a molecular level but at a chromosomal level too. From the introduction of cytological techniques for in situ digestion of chromosomes with restriction endonucleases (Kaelbling et al., 1984) extensive use has been made of this new approach to induce chromosome banding in eukaryotic chromosomes (see López-Fernández et al., 1991, for review) and to analyse DNA methylation

\footnotetext{
${ }^{*}$ Correspondence.
}

patterns at the chromosome level (Bianchi et al., 1986; López-Fernández et al., 1989; Prantera \& Ferraro, 1990; López-León et al., 1991; Loebel \& Johnston, 1993; Suja et al., 1993).

From the first demonstration that DNA methylation may regulate the activity of the rRNA genes in a rat hepatoma cell line (Tantravahi et al., 1981), the phenomenon has been extended to other organisms such as, for instance, peas (Watson et al., 1987), wheat (Flavell et al., 1988), frogs (Ruiz \& Brison, 1989) and mice (Suzuki et al., 1992). Interestingly, DNA methylation also seems to be involved in the inactivation of extra rRNA genes contained in a supernumerary chromosome segment that has arisen from amplification of a nucleolus organiser region (NOR) in the grasshopper Pyrgomorpha conica (Suja et al., 1993).

The grasshopper Eyprepocnemis plorans shows an extensive polymorphism for B chromosomes in natural populations along the Spanish southern Atlantic and Mediterranean coasts (Camacho et al., 1980; Henriques-Gil et al., 1984) characterized by the existence of more than 40 different B variants (HenriquesGil \& Arana, 1990; López-León et al., 1993) and the absence of drive for the three more abundant B-types (López-León et al., 1992). The observation of a male carrying the $\mathrm{B}_{2}$ chromosome fused to the largest auto- 
some and showing the presence of an additional active NOR distaily located on the $B$ itself, suggested the presence of rRNA genes on this B chromosome that are usually inactive but had been reactivated by the chromosomal rearrangement (Cabrero et al., 1987). Additional studies showed that the distal third of the $\mathrm{B}_{2}$ chromosome (where the latent NOR is located) was methylated in normal nonfused Bs that lack NOR activity, but it was not in the fused $B$ that showed NOR activity (López-León et al., 1991), thus showing the typical methylation-inactivity correlation.

Since the results of Cabrero et al. (1987) and LópezLeón et al. (1991) were observed in spermatocytes, and given the dependence of DNA methylation on cell type and developmental stage (see above), we planned the present work in order to analyse methylation patterns on the $\mathrm{B}_{2}$ chromosome in embryos and different adult tissues. This is, to our knowledge, the first attempt at the chromosomal level to ascertain the developmental regulation of gene expression by means of DNA methylation.

\section{Materials and methods}

Adult males and females of Eyprepocnemis plorans were collected in Salobreña on the coast of Granada (Spain) and reared as heterosexual pairs in culture laboratory cages in order to obtain embryo offspring following the technique described in López-León et al. (1992). Females were injected with $0.01 \mathrm{~mL} 0.05$ per cent colchicine in insect saline solution for $6 \mathrm{~h}$ prior to fixation of ovariole and gastric caecae in 3:1 ethanol:acetic acid. Testes were fixed before a colchicine pretreatment, similar to that in females, in order to fix male gastric caeca (Viseras et al., 1990). Egg-pods were incubated for 10 days at $28^{\circ} \mathrm{C}$ and embryos were dissected out of the eggs and immersed in $1 \mathrm{~mL}$ of 0.05 per cent colchicine in insect saline solution for $1 \mathrm{~h}$. One $\mathrm{mL}$ of distilled water was then added for hypotonic shock for $10 \mathrm{~min}$ and then the embryos were fixed in 3:1 ethanol:acetic acid. All fixed materials were stored in a refrigerator at about $4^{\circ} \mathrm{C}$. In addition, several eggpods were incubated to term in order to obtain adult offspring, of which several individuals were fixed at the last instar nymph stage. Chromosomal preparations of adult tissues (testes and gastric caeca in males, and ovarioles and gastric caeca in females) were made by squashing in 50 per cent acetic acid and subsequently removing coverslips after freezing the preparations in liquid $\mathrm{N}_{2}$. Chromosomal preparations of embryos were obtained by the method described in Camacho et al. (1991). NOR activity was analysed by the silver impregnation technique of Rufas et al. (1982). During male meiosis, this technique reveals the nucleoli attached to the active NORs during prophase I. In adult somatic and embryonic tissues, however, NOR activity has to be analysed in early mitotic prophases where chromosome identification is more difficult, because the nucleoli are not visible in later stages. For this reason, sequential silver impregnation and C-banding were performed to facilitate the identification of chromosomes showing active NORs, by means of the technique described in Pardo et al. (1993). Chromosomal methylation patterns were determined by in situ digestion with the MspI and HpaII restriction endonucleases, following the methods described in Sentís et al. (1989) and López-León et al. (1991). In situ hybridization with a ribosomal DNA probe was performed following the technique described in LópezLeón et al. (1994).

\section{Results}

In situ hybridization showed that the B chromosome possesses, located in its distal third, the largest cluster of ribosomal RNA genes in the complement (Fig. 1), including those in chromosomes 9, 10, 11 and $\mathrm{X}$, which are usually the only active NORs in testes (Cabrero et al., 1987), and minor usually inactive rRNA gene clusters in centromeric regions of the remaining chromosomes.

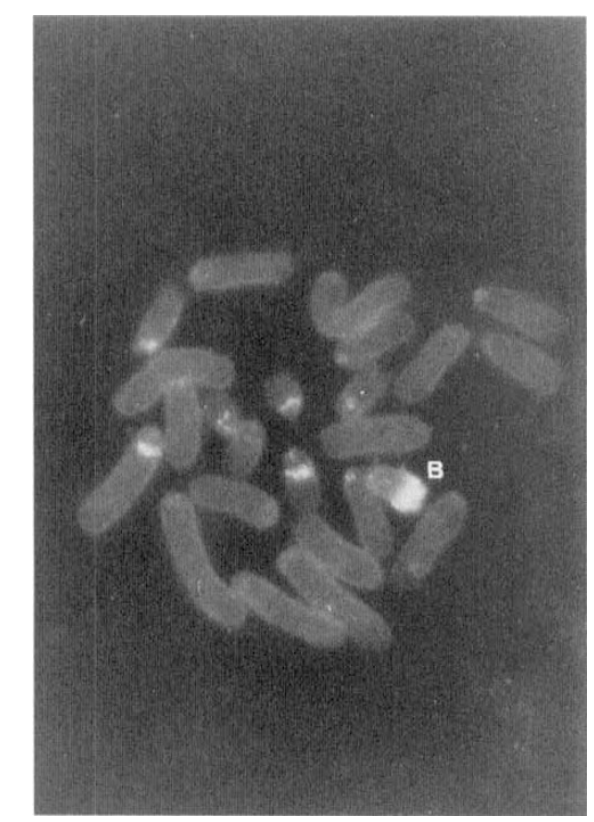

Fig.1 Mitotic metaphase cell from an Eyprepocnemis plorans embryo after fluorescence in situ hybridization with an rDNA probe. Note that the distal third of the $B$ chromosome harbours the largest rRNA gene cluster in the complement. 
The analysis of chromosome methylation patterns in embryos showed that the B-NOR possesses abundant CCGG targets since it is clearly digested by MspI (Fig. 2a). The fact that this chromosome region was also digested by HpaII (Fig. 2b) demonstrated that the B-NOR is not methylated in embryo cells. However, sequential silver impregnation and C-banding of early mitotic prophase cells showed that the B-NOR is inactive in 10-day-old embryos (Fig. 2c). Methylation and activity patterns of the B-NOR were the same in embryos that had inherited the B chromosome from the mother and those that had inherited it from the father.

A similar result was obtained in a somatic tissue (gastric caeca) in last instar nymph and adult individuals of both sexes: the B-NOR was digested by MspI and HpaII suggesting its under-methylation, and sequential silver impregnation and $\mathrm{C}$-banding showed that this NOR is not active in these cells (Fig. 3a).

In gonads, however, the result was different. In spermatocytes (Fig. 3b) and ovariole wall cells (Fig. 3c) (the first being germ cells but the second being somatic cells) the B-NOR was digested by MspI but not by HpaII thus indicating high levels of DNA methylation. However, the B-NOR was not active in either type of cell.

The B chromosome shows a relatively high frequency of spontaneous translocations (always centric fusions) with A chromosomes, so that several cases have already been described (Henriques-Gil et al., 1983; Cabrero et al., 1987). In fact, in populations with a high frequency of B chromosomes, e.g. Salobreña, in almost every year there appears one or more individuals carrying a new centric fusion (López-

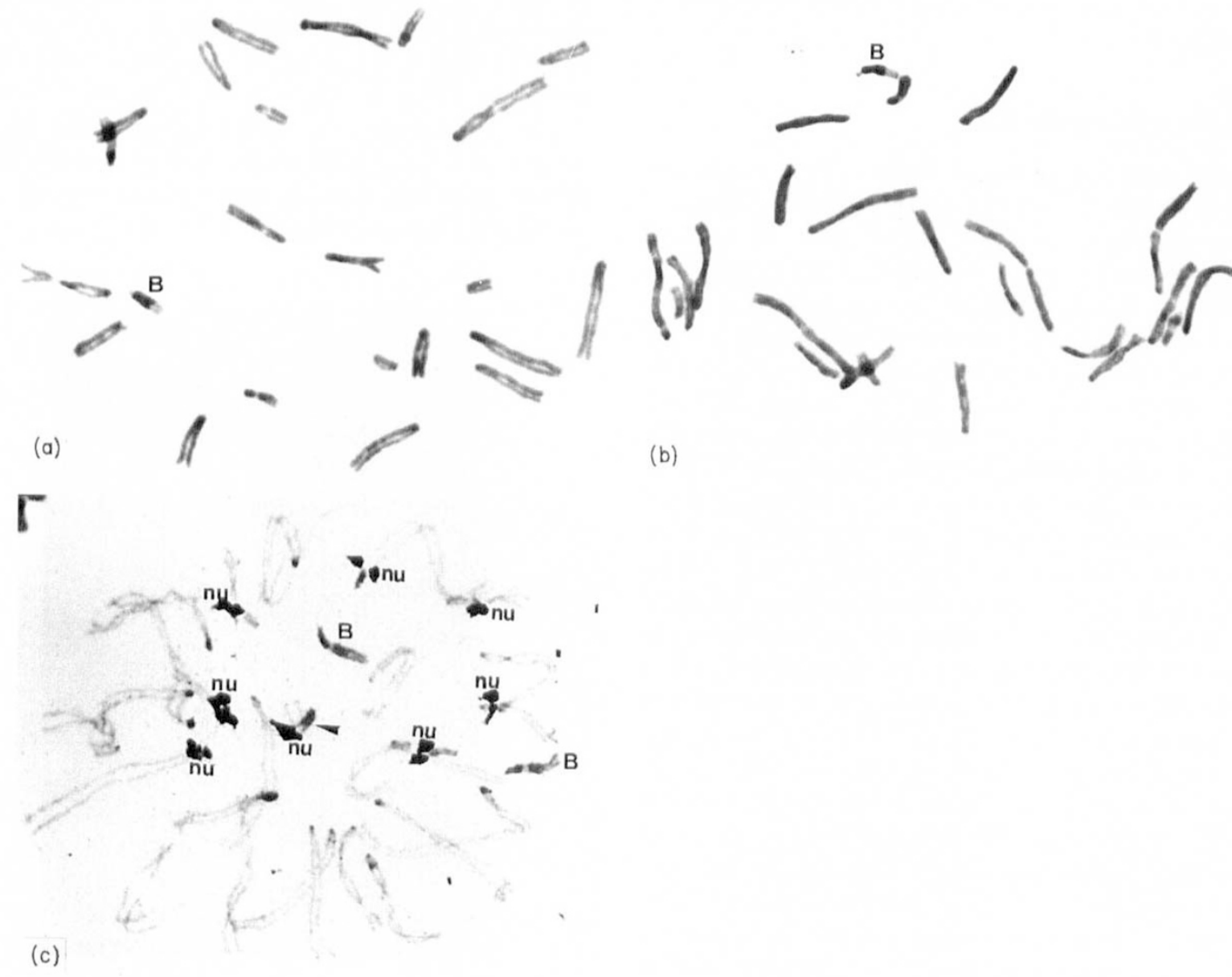

Fig.2 Mitotic metaphase ( $\mathrm{a}$ and $\mathrm{b}$ ) and prophase (c) cells from Eyprepocnemis plorans embryos submitted to in situ digestion with $M s p I$ (a) and HpaII (b) restriction endonucleases and to the double silver impregnation and C-banding technique (c). Observe in (a) and ( $b$ ) that the distal third of the B chromosome is differentially digested by both enzymes thus suggesting that the B-rRNA genes are not methylated. Note in (c) that the two B chromosomes lack a nucleolus (nu) associated with their distal third, which demonstrates that their rRNA genes are not active in this life cycle stage. 
Fig.3 Selected B chromosomes from Eyprepocnemis plorans adults, treated with MspI (1), HpaII (2) and silver impregnation ( 3 and 4 ). In gastric caeca mitotic cells from both males and females, the $\mathrm{B}$ chromosome region harbouring rRNA genes (the distal third) is digested by both enzymes (1a and $2 \mathrm{a}$ ) but does not show nucleolar activity (3a). In spermatocytes at diplotene and ovariole wall mitotic cells, this $\mathrm{B}$ chromosome region is digested by MspI ( $1 \mathrm{~b}$ and $1 \mathrm{c}$ ) but not by HpaII ( $2 \mathrm{~b}$ and $2 c)$ and does not show signs of nucleolar activity ( $3 \mathrm{~b}$ and $3 \mathrm{c})$. In diplotene spermatocytes from an exceptional male showing a spontaneous centric fusion of the B chromosome and the longest autosome (chromosome 1) (reported in Cabrero et al., 1987), the distal third of the B chromosome was digested by both $M s p \mathrm{I}$ (1d) and $H p a I I(2 \mathrm{~d})$, and showed a prominent nucleolus (nu) in about half of the primary spermatocytes at diplotene (3d) and the spermatogonial cells at mitotic prophase (4d). In a female carrying a spontaneous centric fusion between the $\mathrm{B}$ chromosome and the smallest autosome (chromosome 11), the distal region of the $B$ in mitotic metaphase ovariole wall cells was digested by both enzymes ( $1 \mathrm{e}$ and $2 \mathrm{e}$ ) thus suggesting absence of DNA methylation, but sequential silver impregnation and C-banding in prophase cells showed absence of nucleolar activity $(3 \mathrm{e})$. (a)

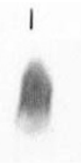

(b)

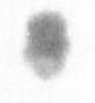

(c)

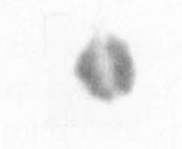

(d)

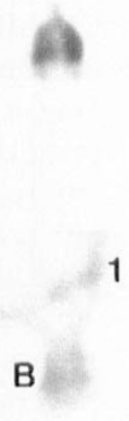

(e)
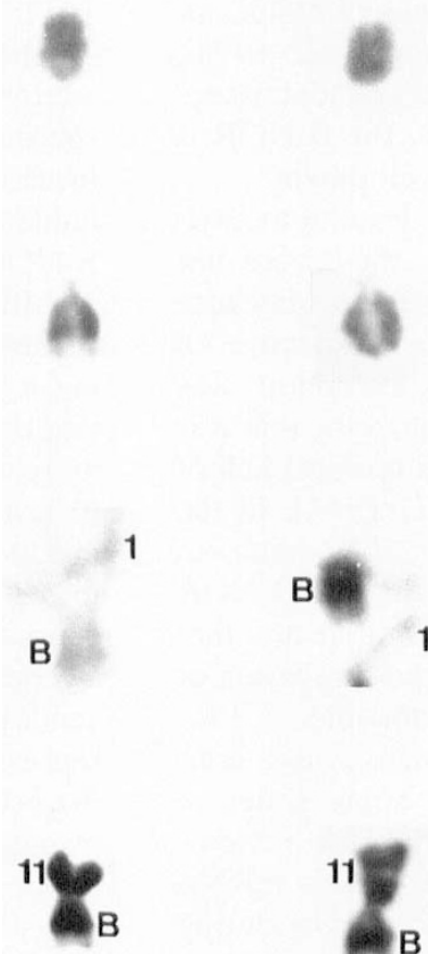
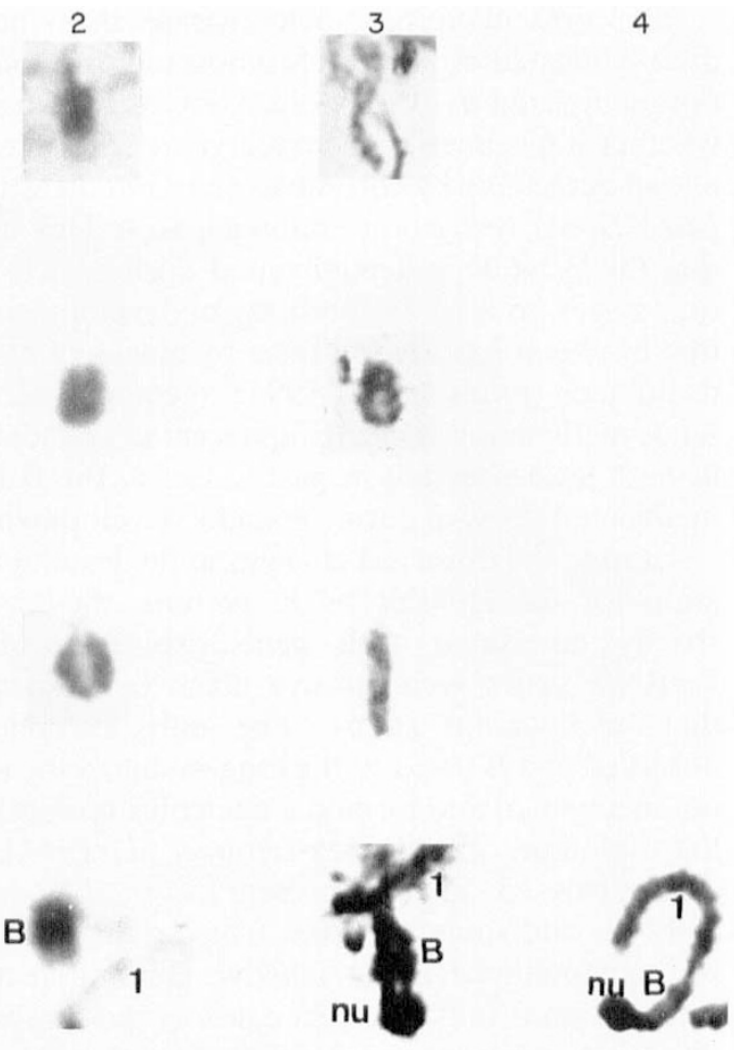

León et al., unpublished). The case of the B chromosome fused to the largest autosome described in Cabrero et al. (1987) was very interesting because this chromosome rearrangement seemed to cause the reactivation of the B-NOR in spermatocytes and it was paralleled by a low level of DNA methylation (LópezLeón et al., 1991). To illustrate this case, we have included here Fig. 3d which shows B-NOR digestion with both $M s p I$ and $H p a I I$ and a nucleolus attached to the distal part of the fused $B$.

We have recently had the opportunity to analyse a female that carried a B chromosome fused to the smallest autosome, the NOR-carrying chromosome 11. The results for this fused $B$ were different from the former in that, although it was digested by both restriction endonucleases (thus showing low methylation level), the B-NOR was always inactive, which contrasted with the activity of the standard NOR in chromosome 11 (Fig. 3e).

\section{Discussion}

Changes in DNA methylation level during embryogenesis have been observed for repetitive DNA (Chapman et al., 1984) and for both tissue-specific and housekeeping genes (Cedar \& Razin, 1990). Molecular techniques have also shown the involvement of DNA methylation in regulating the activity of rRNA genes in rats (Tantravahi et al., 1981), mice (Bird et al., 1981), peas (Watson et al., 1987), wheat (Flavell et al., 1988) and frogs (Ruiz \& Brison, 1989). In two of these cases a relationship was observed between the level of methylation of rRNA genes and the developmental stage (Watson et al., 1987) or age (Ruiz \& Brison, 1989). 
The present results demonstrate that the NOR distally located on the $\mathrm{B}_{2}$ chromosome of $E$. plorans is not methylated in 10-day-old embryos (irrespective of whether it has been transmitted via male or female), at a level detectable by chromosome in situ digestion with $\mathrm{Msp} \mathrm{I} / \mathrm{HpaII}$ restriction endonucleases. This indicates that the B-NOR is demethylated during early embryonic stages prior to the tenth day of development, a fact that has been reported in mice by means of molecular techniques (Frank et al., 1991; Shemer et al., 1991). Since methylation is clearly apparent in gonadal tissues in both sexes but not in gastric caeca, the B-NOR is methylated de novo during gonadal development.

Despite the observed changes in the level of methylation for the B-NOR in E. plorans, they were not strictly correlated with gene expression, because B-rRNA genes were always inactive irrespective of their methylation status. The only exception was observed in a B fused to the longest autosome that was not methylated and formed a nucleolus in about half of the diplotene cells (López-León et al., 1991). In the cells analysed in the present work belonging to embryos and somatic tissues from adults, the B-NOR was not methylated but inactive. This indicates that methylation is not the direct cause of the repression of the rRNA genes carried by the B chromosome.

Similar hypomethylation in both active and nonactive tissues has been reported for some genes in vertebrates (see Yeivin \& Razin, 1993, for review). Likewise, no methylation causes the decrease in mRNA and protein synthesis occurring in chloroplasts during leaf growth and senescence (Tomás et al., 1992). A direct correlation between methylation and expression has been reported even for the $M G M T$ gene in humans (Pieper et al., 1991; Wang et al., 1992). The existence of other factors besides methylation for regulation of the level of expression and switching of the human globin genes has recently been suggested by Loo \& Cáuchi (1992). In this context, several recent results suggest that inhibition of transcription by DNA methylation is an indirect effect (Boyes \& Bird, 1991) and that chromatin structure is a dominant determinant in maintaining the inactive state of genes (Weih et al., 1991).

In the case of E. plorans, the existence of low levels of methylation in the promoter regions of rRNA genes in the $\mathrm{B}$, that would be undetectable by the present chromosomal analysis, cannot be ruled out as a cause of the B-NOR inactivity. However, this does not explain why the apparently unmethylated fused B reported in López-León et al. (1991) showed NOR activity in certain diplotene cells but not in others, unless differential promoter methylation occurs between diplotene cells, and this is unlikely. Further- more, the fact that the NORs on the standard chromosomes $9,10,11$ and $X$ were active in less than 100 per cent of diplotene cells (Cabrero et al., 1987) indicates that the activity pattern was rather similar in standard and B-NORs of that individual, and suggests the possibility that rRNA genes in this fused $B$ were submitted to the same control mechanisms operating on the remaining rRNA gene clusters.

The B chromosome when fused to other autosomes, e.g. the smallest one, also seems to escape from de novo methylation, but it never shows NOR activity in either spermatocytes (P. Arana, personal communication) or ovariole cells (this paper). Thus, DNA methylation is unlikely to be the only cause of the inactivity of the B-NOR.

Although it is necessary to study additional cases of Bs fused to other standard chromosomes before reaching a definitive conclusion, the present data suggest that the nonmethylation of the B-NOR in fused Bs and its reactivation are separate matters. Two possibilities to test in future work are (i) that different B fusions produce different changes in the chromatin structure of the B-NOR so that only some of them facilitate its expression, and (ii) that the longest autosome contains a gene(s) close to the centromere that is involved in the general regulation of NOR expression (presumably repressing the B-NOR) and that this gene is affected by the presence of the fused $B$, which is heterochromatic, by means of a position effect.

\section{Acknowledgements}

We thank Dr. P. Heslop-Harrison for facilities to perform in situ hybridization in his laboratory, Dr. M. Ruiz-Rejón for useful comments, and an anonymous referee for English corrections. This study was partially supported by grants from the Dirección General Científica y Técnica (no. PB90-0865) and the Plan Andaluz de Investigación, Grupo no. 3122 (Spain).

\section{References}

ARIEL, M., McCARREY, J. AND CEDAR, H. 1991. Methylation patterns of testis-specific genes. Proc. Natl. Acad. Sci. U.S.A., 88, 2317-2321.

BIANCHI, N. O., VIDAL-RIOJA, E. L. AND CleAVER, J. E. 1986. Direct visualization of the sites of DNA methylation in human and mosquito chromosomes. Chromosoma, 94, 362-366.

BIRD, A. P. 1986. CpG-rich islands and the function of DNA methylation. Nature, 321, 209-213.

BIRD, A. P., TAGGART, M. H. AND GEHRING, C. A. 1981. Methylated and unmethylated ribsomal RNA genes in the mouse. $J$. Mol. Biol., 152, 1-17. 
BOYES, J. AND BIRD, A. P. 1991. DNA methylation inhibits transcription indirectly via a methyl-CpG binding protein. Cell, 64, 1123-1134.

CABRERO, J., ALCHE, J. D. AND CAMACHO, J. P. M. 1987. Effects of B chromosomes on the activity of nucleolar organizer regions in the grasshopper Eyprepocnemis plorans: activation of a latent nuclear organizer region on a B chromosome fused to an autosome. Genome, 29, 116-121.

CAMACHo, J. P. M., CARBallo, A. R. AND CABrero, J. 1980. The B-chromosome system of the grasshopper Eyprepocnemis plorans subsp. plorans (Charpentier). Chromosoma, 80 , 163-176.

CAMACHO, J. P. M., CABRERO, J., VISERAS, E., LOPEZ-LEON, M. D., NAVAS-CASTILLO, J. AND ALCHE, J. D. 1991. G-banding in two species of grasshoppers and its relationship to $\mathrm{C}, \mathrm{N}$ and fluorescence banding techniques. Genome, 34, 638-643.

CEDAR, H. 1988. DNA methylation and gene activity. Cell, 53, 3-4.

CEDAR, H. AND RAZIN, A. 1990. DNA methylation and development. Biochim. Biophys. Acta, 1049, 1-8.

CHAPMAN, V., FORRESTER, L., SANFORD, J., HASTIE, N. AND ROSSANT, J 1984. Cell lineage-specific undermethylation of mouse repetitive DNA. Nature, 307, 284-286.

FLAVELL, R. B., O'DELL, M. AND THOMPSON, W. F. 1988. Regulation of cytosine methylation in ribosomal DNA and nucleolus organizer expression in wheat. J. Mol. Biol., 204, 523-534.

FRANK, D., KESHET, I., SHANI, M., LEVINE, A., RAZIN, A. AND CEDAR, H 1991. Demethylation of $\mathrm{CpG}$ islands in embryonic cells. Nature, 351, 239-241.

FRONK, J., TANK, G. A. AND LANGMORE, J. P. 1992. DNA methylation pattern changes during development of a sea urchin. Biochem. J., 283, 751-753.

HENRIQUES-GIL, N. AND ARANA, P. 1990. Origin and substitution of B chromosomes in the grasshopper Eyprepocnemis plorans. Evolution, 44, 747-753.

HENRIQUES-GIL, N., ARANA, P. AND SANTOS, J. L. 1983. Spontaneous translocations between $B$ chromosomes and the normal complement in the grasshopper Eyprepocnemis plorans. Chromosoma, 88, 145-148.

HENRIQUES-GIL, N., SANTOS, J. L. AND ARANA, P. 1984. Evolution of a complex B-chromosome polymorphism in the grasshopper Eyprepocnemis plorans. Chromosoma, 89, 290-293.

KAELBLING, M., MILLER, D. A. AND MILlER, O. J. 1984. Restriction enzyme banding of mouse metaphase chromosomes. Chromosoma, 90, 128-132.

LOEBEL, D. A. AND Johnston, P. G. 1993. Analysis of DNase 1 sensitivity and methylation of active and inactive $\mathrm{X}$ chromosomes of kangaroos (Macropus robustus) by in situ nick translation. Chromosoma, 102, 81-87.

LOO, L. S. L. AND CAUCHI, M. N. 1992. DNA methylation patterns of the $\gamma \delta \beta$-globin genes in human fetal and adult erythroid tissues. Am. J. Hematol., 39, 289-293.

LOPEZ-FERNÁNDEZ, C., GOSÁLVEZ, J. AND MEZZANOTTE, R. 1989. Heterochromatin heterogeneity in Oedipoda germanica (Orthoptera) detected by in situ digestion with restriction endonucleases. Heredity, 62, 269-277.

LOPEZ-FERNANDEZ, C., GOSALVEZ, J., FERRUCCI, L. AND MEZZANOTTE, R. 1991a. Restriction endonucleases in the study of eukaryotic chromosomes. Genetica, 83, 257-274.

LÓPEZ-LEÓN, M. D., CABRERo, J. AND CAMACHO, J. P. M. 1991b. A nucleolus organizer region in a $\mathrm{B}$ chromosome inactivated by DNA methylation. Chromosoma, 100, 134-138.

LÓPEZ-LEÓN, M. D., CABRERO, J., CAMACHO, J. P. M., CANO, M. I. AND SANTOS, J. L. 1992. A widespread B chromosome polymorphism maintained without apparent drive. Evolution, 46, 529-539.

LOPEZ-LEON, M. D., CABRERO, J., PARDO, M. C., VISERAS, E., CAMACHO, J. P. M. AND SANTOS, J. L. 1993. Generating high variability of B chromosomes in Eyprepocnemis plorans (grasshopper). Heredity, 71, 352-362.

LOPEZ-LEÓN, M. D., NEVES, N., SCHWARZACHER, T., HESLOPHARRISON, T. S., HEWTTT, G. M., AND CAMACHO, J. P. M. 1994. Possible origin of a B chromosome deduced from its DNA composition using double FISH technique. Chromosome Res., 2, 87-92.

PARDo, M. C., visERAS, E., CABRERO, J. AND CAMACHO, J. P. M. 1993. A supernumerary chromosome segment in Locusta migratoria. Genome, 36, 919-923.

PIEPER, R. O., COSTELLO, J. F., KROES, R. A., FUTSCHER, B. W., MARATHI, U. AND ERICKSON, L. C. 1991. Direct correlation between methylation status and expression of the human O-6Methylguanine DNA Methyltransferase gene. Cancer Comm., 3, 241-253.

PRANTERA, G. AND FERRARo, M. 1990. Analysis of methylation and distribution of $\mathrm{CpG}$ sequences on human active and inactive $\mathrm{X}$ chromosomes by in situ nick translation. Chromosoma, 99, 18-23.

RAZIN, A. AND CEDAR, H. 1991. DNA methylation and gene expression. Microbiol. Rev., 55, 451-458.

RAZIN, A. AND RIGGS, A. D. 1980. DNA methylation and gene function. Science, 210, 604-616.

RUFAS, J. S., ITURRA, P., DE SOUZA, W. AND ESPONDA, P. 1982. Simple silver staining procedure for the localization of nucleolus and nucleolar organizer under light and electron microscopy. Arch. Biol., 93, 267-274.

RUIZ, I. R. G. AND BRISON, o. 1989. Methylation of ribosomal cistrons in diploid and tetraploid Odontophrynus americanus (Amphibia, Anura). Chromosoma, 98, 86-92.

SENTIS, C., SANTOS, J. AND FERNANDEZ-PIQUERAS, J. 1989. In situ methylation of insect chromosomes with methylase HpaII. Chromosoma, 98, 105-108.

SHEMER, R., KAFRI, T., O'CONNELL, A., EISENBERG, S., BRESLOW, J. L. AND RAZIN, A. 1991. Methylation changes in the apolipoprotein AI gene during embryonic development of the mouse. Proc. Natl. Acad. Sci. U.S.A ., 88, 11300-11304.

SUJA, J. A., ANTONIO, C., GONZÁLEZ-GARCIA, J. M. AND RUFAS, J. S. 1993. Supernumerary heterochromatic segments associated with the nucleolar chromosomes of Pyrgomorpha conica (Orthoptera) contain methylated rDNA sequences. Chromosoma, 102, 491-499.

SUZUKI, H., SAKURA,, S., NISHIMURA, M., KOMINAMI, R. AND MORIWAKI, K. 1992. Compensatory changes in silverstainability of nucleolar organizer regions in mice. Jap. J. Genet., 67, 217-232.

TANTRAVAHI, U., GUNTAKA, R. V., ERLANGER, B. F. AND MILLER, O. J. 1981. Amplified ribosomal RNA genes in a rat hepatoma cell line are enriched in 5-methylcytosine. Proc. Natl. Acad. Sci. U.S.A., 78, 489-493. 
TOMÁs, R., VERA, A., MARTÍN, M. AND SABATER, B. 1992. Changes in protein synthesis without evidence of DNA methylation in barley chloroplasts during leaf growth and development. Plant Sci., 85, 71-77.

VISERAS, E., CAMACHO, J. P. M., CANO, M. I. AND SANTOS, J. L. 1990. Relationship between mitotic instability and accumulation of B chromosomes in males and females of Locusta migratoria. Genome, 33, 23-29.

WANG, Y., KATO, T., AYAKI, H., ISHIZAKI, K., TANO, K., MITRA, S. AND IKENAGA, M. 1992. Correlation between DNA methylation and expression of $\mathrm{O}^{6}$-methylguanine-DNA methyltransferase gene in cultured human tumor cells. Mutat. Res., 273, 221-230.
WATSON, J. C., KAUFMAN, L. S. AND THOMPSON, W. F. 1987. Developmental regulation of cytosine methylation in the nuclear ribosomal RNA genes of Pisum sativum. J. Mol. Biol., 193, 15-26.

WEIH, F., NITSCH, D., REIK, A., SCHUTTZ, G. AND BECKER, P. B. 1991. Analysis of $\mathrm{CpG}$ methylation and genomic footprinting at the tyrosine aminotransferase gene: DNA methylation alone is not sufficient to prevent protein binding in vivo EMBO J., 10, 2559-2567.

YEIVIN, A. AND RAZIN, A. 1993. Gene methylation patterns and expression. In: Jost, J. P. and Saluz, H. P. (eds) DNA Methylation: Molecular Biology and Molecular Significance, pp. 523-568. Birkhaüser Verlag, Basel. 